\title{
Effects of Hydroxyurea, Nalidixic Acid and Zinc Limitation on DNA Polymerase and ATP-dependent Deoxyribonuclease Activities of Mycobacterium smegmatis
}

\author{
By F. G. WINDER AND D. S. BARBER \\ Department of Biochemistry, Trinity College, Dublin 2, Ireland
}

(Received 9 November 1972)

\begin{abstract}
SUMMARY
Treatment of growing Mycobacterium smegmatis with hydroxyurea decreased the DNA/protein ratio and markedly increased the specific activities of DNA polymerase and ATP-dependent deoxyribonuclease. These changes were similar to those produced by iron limitation of growth. Treating $M$. smegmatis with nalidixic acid also decreased the DNA/protein ratio but had no effect on the activity of either enzyme. Growth of $M$. smegmatis under conditions of zinc limitation did not diminish the specific activity of DNA polymerase thus not favouring a role for zinc in the action of this enzyme. The activity of the ATP-dependent deoxyribonuclease was, however, slightly increased. In previous reports the specific activity of DNA polymerase in this organism has been seriously underestimated due to interfering deoxyribonuclease and nucleoside triphosphatase. This was corrected by sufficient dilution of the extract. Revised specific activities of DNA polymerase in carbon-limited, nitrogen-limited and iron-limited cultures are, respectively, IO, I 4 , I I and 64 units/mg protein.
\end{abstract}

\section{INTRODUCTION}

Growth of Mycobacterium smegmatis under conditions of iron limitation leads to a diminution in the DNA/protein ratio and a marked increase in specific activities of an ATP-dependent deoxyribonuclease and a DNA polymerase (Winder \& O'Hara, I962; Winder \& Coughlan, I969; Winder \& McNulty, 1970). As part of an investigation of the mechanism of these responses to iron limitation and of the regulation of the activities of these two enzymes, the effects of hydroxyurea and nalidixic acid, which are selective inhibitors of DNA synthesis (Gale, Kendall, McLain \& DuBois, I964; Goss, Deitz \& Cook, I964, I965; Rosenkranz \& Levy, I965), were determined. The effects of zinc limitation on DNA polymerase were studied since Slater, Mildvan \& Loeb (I97I) reported that purified DNA polymerase I from Escherichia coli contains two atoms of zinc/molecule of enzyme and that DNA polymerase from sea-urchin embryos contains four atoms. They suggested that, as $o$-phenanthroline inhibits the polymerase in vitro, zinc plays an essential role in the enzyme's action. Huberman \& Kornberg (1970) also have suggested a role for a divalent metal in binding at one of the sites in this enzyme. A possible test for this hypothesis is to determine whether zinc deficiency in a bacterium decreases the activity of DNA polymerase. It is difficult to demonstrate zinc deficiency in $E$. coli (Ratledge \& Winder, 1964), but limitation of growth by zinc is readily observed in Mycobacterium smegmatis (Winder \& O'Hara, 1962) and, consequently, provides an easy means of applying this test. 


\section{METHODS}

Growth of organism. The strain of Mycobacterium smegmatis (Winder \& O'Hara, 1962) was grown in a medium containing ( $\mathrm{g} / 1$ de-ionized water): glycerol, $20 \mathrm{ml}$; monosodium glutamate, $\mathrm{I}_{4} ; \mathrm{KH}_{2} \mathrm{PO}_{4}, 5 ; \mathrm{K}_{2} \mathrm{SO}_{4}, 0.5$; and $\mathrm{MgSO}_{4} \cdot 7 \mathrm{H}_{2} \mathrm{O}, 0.5$. The $\mathrm{pH}$ was adjusted to 6.8 with $10 \mathrm{M}-\mathrm{NaOH}$ and the medium was autoclaved with alumina (Winder \& Coughlan, I969) to remove trace metals. $\mathrm{Fe}^{2+}\left(2 \mu \mathrm{g} / \mathrm{ml}\right.$ ) and $\mathrm{Zn}^{2+}$ (normally $0.4 \mu \mathrm{g} / \mathrm{ml}$ but $0.012 \mu \mathrm{g} / \mathrm{ml}$ in the zinc-limited medium) were added as their sulphate salts. Cultures were grown at $37^{\circ} \mathrm{C}$ on a rotary shaker.

Nalidixic acid (Calbiochem Ltd, London), in $0 . \mathrm{I} \mathrm{M}-\mathrm{NaOH}$, and hydroxyurea, in water, were sterilized by membrane filtration and were added to a proportion of the cultures after the appropriate period of growth. Bacteria were harvested by filtration under suction on Whatman no. I paper, washed with $0.9 \% \mathrm{NaCl}$, removed from the paper and stored at about $-15{ }^{\circ} \mathrm{C}$. Crude bacteria-free extracts were prepared as described previously (McNulty \& Winder, 197I).

Assays. In the assay of DNA, $2.5 \mathrm{ml} \mathrm{M}-\mathrm{HClO}_{4}$ was added to $\mathrm{I} \mathrm{ml}$ of the bacterial extract and the mixture was heated at $95{ }^{\circ} \mathrm{C}$ for $\mathrm{I} 5 \mathrm{~min}$ and centrifuged. Deoxyribose was measured in the supernatant as previously described (Winder \& Coughlan, 1969), except that $0.3 \mathrm{mg}$ of acetaldehyde, instead of $\mathrm{I} \cdot 6 \mathrm{mg}$, was used.

DNA polymerase was assayed in the bacterial extracts as described by McNulty \& Winder (197I), except that twofold serial dilutions of each extract were assayed and the specific activity was calculated from the results for the dilution which gave nearest to 0.35 unit of enzyme/assay. Units are defined by McNulty \& Winder (1971).

ATP-dependent deoxyribonuclease was assayed in the extracts (Winder \& Lavin, I97I) except that $4 \mu$ moles of ATP were used/incubation mixture. Units are defined as previously.

The assay of glycerol dehydrogenase and the units employed were as described by Winder \& O'Hara (1964).

Protein was measured by the method of Lowry, Rosebrough, Farr \& Randall (1951), using bovine serum albumin as the standard.

\section{RESULTS}

Re-examination of the specific activity of DNA polymerase in Mycobacterium smegmatis. While investigating the reliability of assays of DNA polymerase in crude extracts of $M$. smegmatis considerable interference was observed which caused a serious underestimation of the activity. This was demonstrated to be due, at least partially, to nucleoside triphosphatase and deoxyribonuclease activities in these extracts: pre-incubation of either the deoxyribonucleoside triphosphates or the DNA with the crude extracts, before adding the remainder of the assay components, decreased the apparent activity still further.

When the extracts were serially diluted, the observed specific activity of the enzyme increased to a plateau value, which was maintained over about an eightfold range of dilution. When dilutions which gave specific activities in this plateau region were employed, interference by deoxyribonuclease and nucleoside triphosphatase activities was almost eliminated, as shown by pre-incubating the diluted extracts with the DNA or with the deoxyribonucleoside triphosphates which led to very little diminution in polymerase activity.

This plateau region, in which the observed total incorporation of $\left[\right.$ methyl $\left.{ }^{3} \mathrm{H}\right]$ thymidine 5 -phosphate responded in linear fashion to the amount of enzyme used, varied somewhat depending on the growth conditions of the bacteria. However, an observed activity of 
Table I. Specific activity of DNA polymerase in extracts prepared from Mycobacterium smegmatis grown with different nutrient limitations

Bacteria were grown, extracts were prepared and assays were carried out as described under Methods.

$\begin{array}{lcc}\begin{array}{c}\text { Age of culture } \\ \text { Type of culture }\end{array} & \begin{array}{c}\text { Specific activity } \\ \text { of DNA polymerase } \\ \text { (units/mg of protein) }\end{array} \\ \text { 'Fully sufficient' } & 48 & 8 \cdot 6 \\ & 72 & 10 \cdot 5 \\ \text { Carbon-limited } & 96 & 9 \cdot 0 \\ & 48 & 10 \cdot 4 \\ \text { Nitrogen-limited } & 72 & 14 \cdot 0 \\ & 96 & 12 \cdot 1 \\ \text { Iron-limited } & 48 & 7 \cdot 9 \\ & 72 & 10 \cdot 1 \\ & 96 & 11 \cdot 2 \\ & 72 & 64 \cdot 1\end{array}$

0.35 unit of enzyme/assay mixture always fell within this region. For this reason, each extract was assayed in serial dilution and the specific activity was calculated from the results for the dilution which gave nearest to 0.35 unit of enzyme/assay mixture.

Because these findings indicated that earlier determinations (Winder \& McNulty, I970; McNulty \& Winder, I97I) had given seriously low values for the specific activity of DNA polymerase in crude extracts of Mycobacterium smegmatis, a re-investigation under various growth conditions was undertaken. A comparison of the DNA polymerase activity of cultures of $M$. smegmatis at various stages of growth shows that the activity did not vary much during growth of carbon-limited or nitrogen-limited cultures, or cultures grown in a medium in which excess nutrients were supplied (Table I). This accords with previous results (Winder \& McNulty, I970; McNulty \& Winder, I97I), though the actual values were about 20 times higher. Extracts of iron-limited bacteria had much higher specific activities than did extracts of the other cultures, in keeping with previous observations, though in this case the activities were about 40 times higher.

Effects of nalidixic acid treatment. Much higher concentrations of nalidixic acid were required to exert effects on Mycobacterium smegmatis than on Escherichia coli; over $100 \mu \mathrm{g} / \mathrm{ml}$ was required to partially inhibit an inoculum of $M$. smegmatis in a tube dilution test. When it was added at $200 \mu \mathrm{g} / \mathrm{ml}$ to young, growing cultures of $M$. smegmatis, and these harvested $19 \mathrm{~h}$ later, substantial inhibition of growth was observed (Table 2). However, as the DNA/protein ratio was decreased, either DNA synthesis had been strongly inhibited or some degradation of DNA had taken place. The decline in this ratio though was less marked than has been reported for E. coli (Goss et al. 1964), and no obvious elongation of the bacteria occurred. No appreciable change in DNA polymerase or ATPdependent deoxyribonuclease was observed.

Effects of hydroxyurea treatment. In a tube-dilution test, $200 \mu \mathrm{g}$ hydroxyurea $/ \mathrm{ml}$ allowed virtually no growth of an inoculum of Mycobacterium smegmatis, while $50 \mu \mathrm{g} / \mathrm{ml}$ was partially inhibitory. When it was added at 50 and $200 \mu \mathrm{g} / \mathrm{ml}$ to young, growing cultures of this organism and these were harvested $\mathrm{I} 6 \mathrm{~h}$ later, the DNA/protein ratio of the bacteria was markedly decreased with the specific activities of DNA polymerase and ATP-dependent deoxyribonuclease in the extracts being increased (Table 3 ). These effects were more marked at the higher drug concentration. 
Table 2. Effects of nalidixic acid on growing cultures of Mycobacterium smegmatis

Mycobacterium smegmatis was grown for $28 \mathrm{~h}$ in 'fully sufficient' medium. Nalidixic acid $(200 \mu \mathrm{g} / \mathrm{ml})$ was added after $28 \mathrm{~h}$ and after a further $19 \mathrm{~h}$ the control and treated cultures were harvested. Extracts were prepared and assays carried out as described under Methods.

$\begin{array}{ccccc}\text { Yield } & \begin{array}{c}\text { DNA content } \\ (\mu \text { mol of } \\ \text { Culture }\end{array} & \begin{array}{c}\text { nucleotide/mg } \\ \text { of protein) }\end{array} & \begin{array}{c}\text { DNA polymerase } \\ \text { activity } \\ \text { (units/mg of } \\ \text { protein) }\end{array} & \begin{array}{c}\text { ATP-dependent } \\ \text { deoxyribonuclease } \\ \text { activity } \\ \text { (units/mg of } \\ \text { protein) }\end{array} \\ \text { Control } & 2.09 & 0.257 & 12.4 & 92.6 \\ \text { Nalidixic acid-treated } & 0.94 & 0.188 & 12.8 & 87.2\end{array}$

Table 3. Effects of hydroxyurea on growing cultures of Mycobacterium smegmatis

Mycobacterium smegmatis was grown in 'fully sufficient' medium. Hydroxyurea $(50 \mu \mathrm{g} / \mathrm{ml}$ or $200 \mu \mathrm{g} / \mathrm{ml}$ ) was added after $35 \mathrm{~h}$. Treated and untreated cultures were harvested after a further $\mathrm{I} 6 \mathrm{~h}$ of incubation. Extracts were prepared and assays carried out as described under Methods.

\begin{tabular}{|c|c|c|c|c|}
\hline Culture & $\begin{array}{c}\text { Yield } \\
\text { (g wet wt/l) }\end{array}$ & $\begin{array}{l}\text { DNA content } \\
(\mu \text { mol of } \\
\text { nucleotide } / \mathrm{mg} \\
\text { of protein })\end{array}$ & $\begin{array}{l}\text { DNA polymerase } \\
\text { activity } \\
\text { (units/mg of } \\
\text { protein) }\end{array}$ & $\begin{array}{l}\text { ATP-dependent } \\
\text { deoxyribonuclease } \\
\text { activity } \\
\text { (units/mg of } \\
\text { protein) }\end{array}$ \\
\hline l (35 h) & $1 \cdot 03$ & 0.249 & $16 \cdot 4$ & $55 \cdot 7$ \\
\hline$l(5 I h)$ & $\vec{F}$ & 0.250 & 13.9 & $58 \cdot 0$ \\
\hline $\begin{array}{l}\text { xyurea } \\
\mathrm{g} / \mathrm{ml})(5 \mathrm{~h})\end{array}$ & $3 \cdot 60$ & $0.14 \mathrm{I}$ & $23 \cdot 4$ & $90 \cdot 0$ \\
\hline $\begin{array}{l}\text { xyurea } \\
\mathrm{g} / \mathrm{ml})(5 \mathrm{~L}\end{array}$ & $2 \cdot 74$ & 0.095 & $36 \cdot 4$ & I 36 \\
\hline
\end{tabular}

Microscopic examination showed that the vast majority of the bacteria grown in $50 \mu \mathrm{g}$ hydroxyurea $/ \mathrm{ml}$ were longer than the control bacteria, though the elongation was less than when the bacteria were grown under iron limitation. When $200 \mu \mathrm{g}$ hydroxyurea/ml was used, elongation was less marked, presumably because of more complete inhibition of growth.

Effects of zinc limitation. When Mycobacterium smegmatis was grown in zinc-limited medium the growth rate began to diverge from that of the unlimited cultures after about $48 \mathrm{~h}$ (Fig. I), indicating that zinc limitation began to affect growth at about that time. Zinc limitation had, however, begun to affect other processes earlier than this; by $48 \mathrm{~h}$ the specific activity of glycerol dehydrogenase, which serves as a sensitive indicator of zinc deficiency in this organism (Winder \& O'Hara, r964), was below that in the control bacteria. The DNA/protein ratios were not substantially different from those in the controls. The specific activity of the ATP-dependent deoxyribonuclease rose markedly above that in the control bacteria after about $48 \mathrm{~h}$. In this, and other similar experiments, the specific activity of DNA polymerase never fell below that in the control bacteria, even when zinc deficiency had been established for a considerable period. In fact, DNA polymerase activity in the zinc-deficient bacteria invariably tended to rise slightly above that in the control bacteria.

Our main interest in the effects of zinc limitation was concerned with a possible role of zinc in the action of DNA polymerase. The case for such a role is based partly on the demonstration that DNA polymerases from several sources are inhibited by $o$-phenanthroline (Slater et al. I97I). Hence, if the results with the Mycobacterium smegmatis were to be relevant in this context, its DNA polymerase must also be inhibited by $o$-phenan- 

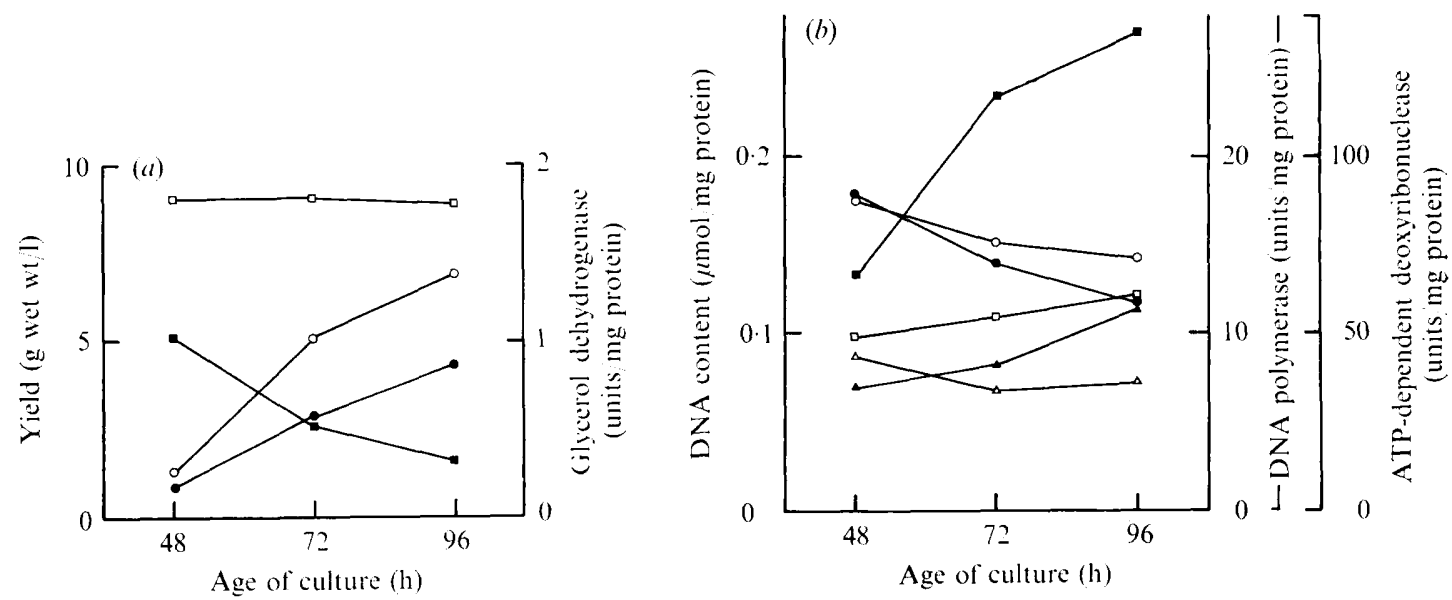

Fig. I. Comparison of 'fully sufficient' and zinc-limited cultures of Mycobacterium smegmatis. Fully sufficient cultures are indicated by open symbols and zinc-limited by closed symbols. Extracts were prepared and assays carried out as described under Methods. (a) Yield of bacteria $(O, \odot)$ and specific activity of glycerol dehydrogenase in extracts $(\square, \square)$. (b) DNA content of bacteria $(O, O)$; specific activity of DNA polymerase in extracts $(\triangle, \Delta)$; specific activity of ATP-dependent deoxyribonuclease in extracts $(\square, \boldsymbol{\square})$.

\section{Table 4. Inhibition of partially purified DNA polymerase of Mycobacterium smegmatis by o-phenanthroline}

The DNA polymerase was purified from iron-limited Mycobacterium smegmatis as described by McNulty \& Winder (1971). Assays were carried out as described under Methods, in the presence of the specified concentrations of $o$-phenanthroline.

Concentration of
$o$-phenanthroline
$(\mu \mathrm{M})$
0
$2 \mathrm{I}$
$4 \mathrm{I}$
83
165
370
660

$\begin{gathered}\text { Activity of } \\ \text { DNA polymerase } \\ \text { (units) } \\ 0.854 \\ 0.795 \\ 0.536 \\ 0.169 \\ 0.107 \\ 0.102 \\ 0.093\end{gathered}$

Inhibition
$(\%)$
0
7
37
80
88
88
89

throline; with a partially purified DNA polymerase from $M$. smegmatis $50 \%$ inhibition was caused by $50 \mu \mathrm{M} o$-phenanthroline (Table 4). This sensitivity to $o$-phenanthroline is similar to that of the enzyme from Escherichia coli and greater than that of the other DNA polymerases reported (Slater et al. I97I).

\section{DISCUSSION}

The specific activity of DNA polymerase in crude extracts of Mycobacterium smegmatis is much higher than previously reported (Winder \& McNulty, 1970; McNulty \& Winder, 197I). The revised figures are Io units of DNA polymerase $/ \mathrm{mg}$ protein in extracts of normal bacteria and over 60 units/mg protein in iron-limited bacteria. Thus, allowing differences in units employed, the specific activities are of the same order as those found with crude extracts of Escherichia coli (Richardson, Schildkraut, Aposhian \& Kornberg, I964), Micro- 
coccus lysodeikticus (Zimmerman, 1966; Litman, 1968) and Bacillus subtilis (Okazaki \& Kornberg, 1964), though differences in assay conditions make exact comparisons impossible. Iron-limited $M$. smegmatis appears to be an unusually rich source of the enzyme.

The effects produced in Mycobacterium smegmatis by hydroxyurea treatment are remarkably similar to those produced by iron limitation (Winder \& O'Hara, 1962; Winder \& Coughlan, I969; Winder \& McNulty, 1970). In both cases there is bacterial elongation, a fall in the DNA/protein ratio (indicative of a selective inhibition of DNA synthesis) and a marked increase in the specific activities of DNA polymerase and of ATP-dependent deoxyribonuclease. The increases in enzymatic activities on hydroxyurea treatment were not as great as in iron limitation, though further adjustment of drug concentration and exposure time might increase the effects in the former case. Thus, two conditions inhibitory to DNA synthesis increase the activities of these two enzymes in this organism. However, the two mechanisms of inhibition of DNA synthesis are possibly closely related, since iron limitation (Winder \& Coughlan, 197I) and hydroxyurea (Neuhard, I967; Krakoff, Brown \& Reichard, 1968) both may inhibit DNA synthesis by inhibiting ribonucleotide reductase. In fact, hydroxyurea could act by chelating iron in ribonucleotide reductase (Moore, I969).

The increases in activity of the two enzymes in iron limitation and on hydroxyurea treatment do not appear to be due to a fall in the DNA/protein ratio or inhibition of DNA synthesis per se, since nalidixic acid can lead to a similar, though smaller, fall in the DNA/ protein ratio without increasing the specific activities of these enzymes. If both of these treatments do act by inhibiting ribonucleotide reductase, then the increases in activity may be a direct consequence of the altered deoxyribonucleotide pool. Perhaps the most plausible explanation, however, is that such an alteration in the deoxyribonucleotide pool may lead to the formation of abnormal DNA and this may provoke increased production of these enzymes: thymine starvation leads, not only to altered deoxyribonucleotide pools, but also to the formation of abnormal DNA (Gold \& Hurwitz, 1963; Luzzati, I966; Freifelder, I969; Walker, I970).

The DNA polymerase of Mycobacterium smegmatis is similar to DNA polymerase I of Escherichia coli (McNulty \& Winder, I97I) and, hence, is likely to be involved in excision repair (Kelly, Atkinson, Huberman \& Kornberg, 1969). Similarly, the ATP-dependent deoxyribonuclease of $M$. smegmatis is similar to ATP-dependent deoxyribonucleases in E. coli and Diplococcus pneumoniae (Winder \& Lavin, 1971) and, hence, is likely to be involved in recombination repair (Rupp, Wilde, Reno \& Howard-Flanders, 1971) and perhaps also excision repair (Cooper \& Hanawalt, I972). Hence, a reasonable hypothesis is that iron limitation and hydroxyurea treatment leads to the formation of abnormal DNA in $M$. smegmatis and that this induces increased production of repair enzymes. A marked increase in the specific activity of DNA polymerase in Tetrahymena pyriformis follows u.v. irradiation, thymine starvation or ethidium bromide treatment (Crerar \& Pearlman, 1971; Keiding \& Westergaard, 197I), and has been interpreted as a response to an increased need for repair, while in Ustilago maydis irradiation is thought to induce a recombination repair mechanism (Holliday, I97I).

Neither iron limitation nor hydroxyurea treatment increases the DNA polymerase in Escherichia coli. Although iron limitation in E. coli produces bacterial elongation (Ratledge \& Winder, 1964) reminiscent of that in Mycobacterium smegmatis, no appreciable alteration either in DNA/protein ratio or in specific activity of DNA polymerase has been observed (F. G. Winder \& D. S. Barber, unpublished observations). Hydroxyurea selectively inhibits DNA synthesis in $E$. coli, but this is not followed by an appreciable alteration in the DNA polymerase level (F. G. Winder \& P. B. Davis, unpublished observations). 
Investigations with zinc-limited Mycobacterium smegmatis provide no evidence in favour of a role for zinc in the action of DNA polymerase, since the activity of this enzyme did not decline even in severe zinc deficiency. Although this evidence does not disprove such a role, since the polymerase may have much higher affinity for zinc than most other zincrequiring components of the bacteria, it does make the role less likely.

We thank Miss Angela Laverty for technical assistance. This work was supported by grants from the National Science Council of Ireland and the Irish Cancer Society.

\section{REFERENCES}

CoOper, P. K. \& Hanawalt, P. C. (I972). Role of DNA polymerase I and the rec system in excision-repair in Escherichia coli. Proceedings of the National Academy of Sciences of the United States of America 69, II 56-II60.

Crerar, M. \& Pearlman, R. E. (197I). DNA polymerase activity from Tetrahymena pyriformis. FEBS Letters 18, $23 \mathrm{I}-237$.

FreifELDER, D. (I969). Single-strand breaks in bacterial DNA associated with thymine starvation. Journal of Molecular Biology 45, I-7.

Gale, G. R., Kendall, S. M., McLain, H. H. \& DuBois, S. (1964). Effect of hydroxyurea on Pseudomonas aeruginosa. Cancer Research 24, I012-1016.

Gold, M. \& Hurwitz, J. (I963). The enzymatic methylation of the nucleic acids. Cold Spring Harbor Symposia on Quantitative Biology 28, 149-156.

Goss, W. A., DeItz, W. H. \& Cook, T. M. (1964). Mechanism of action of nalidixic acid on Escherichia coli. Journal of Bacteriology 88, I I 2-I I 8 .

Goss, W. A., DeITz, W. A. \& Cook, T. M. (1965). Mechanism of action of nalidixic acid on Escherichia coli. Journal of Bacteriology 89, I068-1074.

Holliday, R. (1971). Biochemical measure of the time and frequency of radiation-induced allelic recombination in Ustilago. Nature New Biology 232, 233-236.

Huberman, J. A. \& Kornberg, A. (1970). Enzymatic synthesis of deoxyribonucleic acid. XXXV. A 3'hydroxylribonucleotide binding site of Escherichia coli deoxyribonucleic acid polymerase. Journal of Biological Chemistry 245, 5326-5334.

Keiding, J. \& WestergaArd, O. (I97I). Induction of DNA polymerase activity in irradiated Tetrahymena cells. Experimental Cell Research 64, 3I7-322.

Kelly, R. B., Atkinson, M. R., Huberman, J. A. \& Kornberg, A. (1969). Excision of thymine dimers and other mismatched sequences by DNA polymerase of Escherichia coli. Nature, London 224, 495-50I.

Krakoff, I. H., Brown, N. C. \& Reichard, P. (I968). Inhibition of ribonucleoside diphosphate reductase by hydroxyurea. Cancer Research 28, I 559-1 565 .

Litman, R. M. (1968). A deoxyribonucleic acid polymerase from Micrococcus luteus (Micrococcus lysodeikticus) isolated on deoxyribonucleic acid-cellulose. Journal of Biological Chemistry 243, 6222-6233.

Lowry, O. H., Rosebrough, N. J., Farr, A. L. \& Randall, R. J. (I95I). Protein measurement with the Folin phenol reagent. Journal of Biological Chemistry 193, 265-275.

LuzzaTI, D. (I966). Effect of thymine starvation on messenger ribonucleic acid synthesis in Escherichia coli. Journal of Bacteriology 92, I435-1446.

MCNulty, M. S. \& Winder, F. G. (I97I). Partial purification and properties of a DNA polymerase from Mycobacterium smegmatis. Biochimica et biophysica acta 254, 2 I3-225.

Moore, E. C. (1969). The effects of ferrous ion and dithioerythritol on inhibition by hydroxyurea of ribonucleotide reductase. Cancer Research 29, 29 I-295.

NeuhaRD, J. ( I 967). Studies on the acid-soluble nucleotide pool in Escherichia coli. IV. Effects of hydroxyurea. Biochimica et biophysica acta $\mathbf{1 4 5}, \mathrm{x}-6$.

OKazaki, T. \& Kornberg, A. (1964). Enzymatic synthesis of deoxyribonucleic acid. XV. Purification and properties of a polymerase from Bacillus subtilis. Journal of Biological Chemistry 239, 259-268.

RATledGe, C. \& Winder, F. G. (1964). Effect of iron and zinc on growth patterns of Escherichia coli in an iron-deficient medium. Journal of Bacteriology 87, 823-827.

Richardson, C. C., Schildkraut, C. L., Aposhian, H. V. \& Kornberg, A. (I964). Enzymatic synthesis of deoxyribonucleic acid. XIV. Further purification and properties of deoxyribonucleic acid polymerase of Escherichia coli. Journal of Biological Chemistry 239, 222-232. 
Rosenkranz, H.S. \& Levy, J. A. (1965). Hydroxyurea: a specific inhibitor of deoxyribonucleic acid synthesis. Biochimica et biophysica acta $95, \mathrm{I} 8 \mathrm{I}-183$.

Rupp, D. W., Wilde, III, C. E., Reno, D. L. \& Howard-Flanders, P. (197I). Exchanges between DNA strands in ultraviolet-irradiated Escherichia coli. Journal of Molecular Biology 6r, 25-44.

Slater, J. P., Mildvan, A. S. \& Loeb, L. A. (I97 I). Zinc in DNA polymerases. Biochemical and Biophysical Research Communications 44, 37-43.

WALKER, J. R. (1970). Thymine starvation and single-strand breaks in chromosomal deoxyribonucleic acid in Escherichia coli. Journal of Bacteriology 104, I39I-I 392.

Winder, F. G. \& COUGHLAN, M. P. (1969). A nucleoside triphosphate-dependent deoxyribonucleic acidbreakdown system in Mycobacterium smegmatis, and the effect of iron limitation on the activity of this system. Biochemical Journal IIx, 679-687.

WINDER, F. G. \& COUGHLAN, M. P. (197I). Comparison of the effects of carbon, nitrogen and iron limitation on the growth and on the RNA and DNA content of Mycobacterium smegmatis. Irish Journal of Medical Science I40, 16-25.

Winder, F. G. \& LAVIN, M. F. (1971). Partial purification and properties of a nucleoside triphosphatedependent deoxyribonuclease from Mycobacterium smegmatis. Biochimica et biophysica acta 247, 542-561.

WiNDER, F. G. \& MCNULTY, M. S. (1970). Increased DNA polymerase activity accompanying decreased DNA content in iron-deficient Mycobacterium smegmatis. Biochimica et biophysica acta 209, 578-586.

WiNDER, F. G. \& O'HARA, C. (I962). Effects of iron deficiency and of zinc deficiency on the composition of Mycobacterium smegmatis. Biochemical Journal 82, 98-108.

WINDER, F. G. \& O'HARA, C. (IS64). Effects of iron deficiency and of zinc deficiency on the activities of some enzymes in Mycobacterium smegmatis. Biochemical Journal 9o, 122-126.

Zimmerman, B. K. (1966). Purification and properties of deoxyribonucleic acid polymerase of Micrococcus lysodeikticus. Journal of Biological Chemistry 24I, 2035-204I. 